Earthquake Hazards Program and Landslide Hazards Program

\title{
Landslides Triggered by the August 14, 2021, Magnitude 7.2 Nippes, Haiti, Earthquake
}

Open-File Report 2021-1112 



\section{Landslides Triggered by the August 14, 2021, Magnitude 7.2 Nippes, Haiti, Earthquake}

By Sabrina N. Martinez, Kate E. Allstadt, Stephen L. Slaughter, Robert Schmitt, Elaine Collins, Lauren N. Schaefer, and Sonia Ellison

Earthquake Hazards Program and Landslide Hazards Program

Open-File Report 2021-1112 


\section{U.S. Geological Survey, Reston, Virginia: 2021}

For more information on the USGS - the Federal source for science about the Earth, its natural and living resources, natural hazards, and the environment-visit https://www.usgs.gov or call 1-888-ASK-USGS.

For an overview of USGS information products, including maps, imagery, and publications, visit https://store.usgs.gov/.

Any use of trade, firm, or product names is for descriptive purposes only and does not imply endorsement by the U.S. Government.

Although this information product, for the most part, is in the public domain, it also may contain copyrighted materials as noted in the text. Permission to reproduce copyrighted items must be secured from the copyright owner.

Suggested citation:

Martinez, S.N., Allstadt, K.E., Slaughter, S.L., Schmitt, R., Collins, E., Schaefer, L.N., and Ellison, S., 2021, Landslides triggered by the August 14, 2021, magnitude 7.2 Nippes, Haiti, earthquake: U.S. Geological Survey Open-File Report 2021-1112, 17 p., https://doi.org/10.3133/ofr20211112.

Associated data for this publication:

Martinez, S.N., Allstadt, K.E., Slaughter, S.L., Schmitt, R.G., Collins, E., Schaefer, L.N., and Ellison, S., 2021, Rapid response landslide inventory for the 14 August 2021 M7.2 Nippes, Haiti, earthquake: U.S. Geological Survey data release, https://doi.org/10.5066/P99MYPXK.

ISSN 2331-1258 (online) 


\section{Acknowledgments}

Funding for the preparation of this report was provided by the U.S. Agency for International Development's Bureau for Humanitarian Assistance and the U.S. Geological Survey. We thank Robert Mason, Karl Winters, and Allen Gellis for their insights on channel sedimentation and flooding and Jeff Coe, Randall Jibson, David Wald, and Ryan Gold for reviewing the report (U.S. Geological Survey). 



\section{Contents}

Acknowledgments ……...................................................................................................................

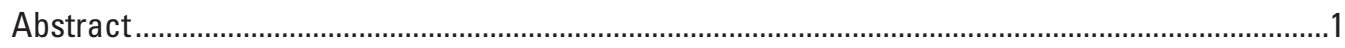

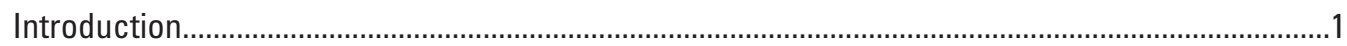

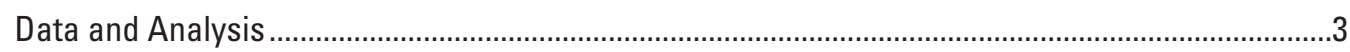

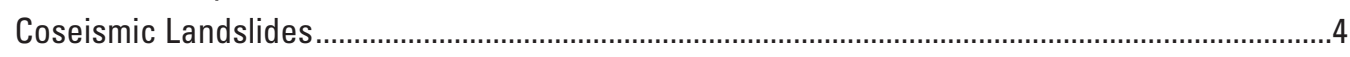

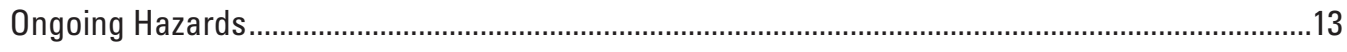

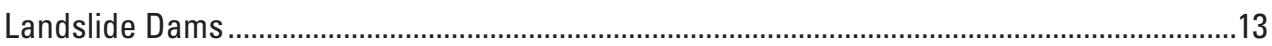

Landslide Hazards to Roads..............................................................................................

Increased Landslide Activity .................................................................................................13

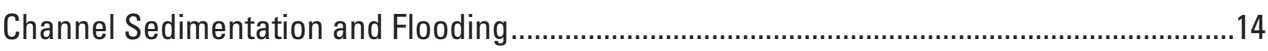

Summary

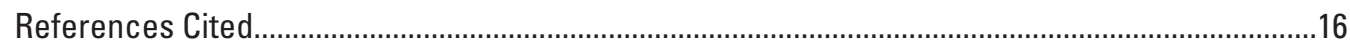

\section{Figures}

1. Overview of the Tiburon Peninsula showing contours of estimated peak ground acceleration for the 2021 Nippes, Haiti, earthquake ........................................................

2. Overview map of the Haiti 2021 earthquake landslide inventory showing landslide dams, road hazards, and flagged landslides ..................................................

3. Flagged landslide features in Camp-Perrin commune, identified from satellite imagery after the 2021 Haiti earthquake ........................................................................

4. Flagged landslide features in Pestel, Beaumont, Chantal, and Roseaux communes, identified from satellite imagery after the 2021 Haiti earthquake..................9

5. Flagged landslide features in Maniche commune, identified from satellite imagery after the 2021 Haiti earthquake .....................................................................10

6. Flagged landslide features in L'Asile commune, identified from satellite imagery after the 2021 Haiti earthquake .................................................................................11

7. Flagged landslides in Cavaillon, Saint Louis du Sud, and Baradères communes, identified from satellite imagery after the 2021 Haiti earthquake.....................................12

8. Satellite imagery from Haiti after the 2021 earthquake and examples of two landslide dams that were flagged as warranting continued monitoring...

9. Map showing the relative density of landslides along 1,000-meter river segments on the Tiburon Peninsula, Haiti, after the 2021 earthquake.

\section{Table}

1. Notable landslide dams and road obstructions after the 2021 Nippes, Haiti, earthquake 


\section{Conversion Factors}

International System of Units to U.S. customary units

\begin{tabular}{lcl}
\hline & Multiply & \multicolumn{1}{c}{ Bo obtain } \\
\hline meter $(\mathrm{m})$ & Length & \\
kilometer $(\mathrm{km})$ & 3.281 & foot $(\mathrm{ft})$ \\
kilometer $(\mathrm{km})$ & 0.6214 & mile $(\mathrm{mi})$ \\
meter $(\mathrm{m})$ & 0.5400 & mile, nautical $(\mathrm{nmi})$ \\
& 1.094 & yard $(\mathrm{yd})$ \\
\hline square kilometer $\left(\mathrm{km}^{2}\right)$ & Area & \\
square kilometer $\left(\mathrm{km}^{2}\right)$ & 247.1 & acre \\
\hline
\end{tabular}

\section{Datum}

Coordinate information is referenced to the World Geodetic System 1984 (WGS 84) Universal Transverse Mercator (UTM) Zone 18N projection.

\section{Abbreviations}

$\begin{array}{ll}\text { DART } & \text { disaster assistance response team } \\ \text { DEM } & \text { digital elevation model } \\ \mathrm{g} & \text { acceleration of gravity } \\ M & \text { magnitude } \\ \text { RMT } & \text { response management team } \\ \text { UNICEF } & \text { United Nations Children's Fund } \\ \text { USAID } & \text { U.S. Agency for International Development } \\ \text { USGS } & \text { U.S. Geological Survey } \\ \text { UTC } & \text { coordinated universal time } \\ \text { UTM } & \text { Universal Transverse Mercator } \\ \text { WGS } & \text { World Geodetic System }\end{array}$




\title{
Landslides Triggered by the August 14, 2021, Magnitude 7.2 Nippes, Haiti, Earthquake
}

\author{
By Sabrina N. Martinez, ${ }^{1}$ Kate E. Allstadt, ${ }^{1}$ Stephen L. Slaughter, ${ }^{1,2}$ Robert Schmitt, ${ }^{1}$ Elaine Collins, ${ }^{1}$ Lauren N. \\ Schaefer, ${ }^{1}$ and Sonia Ellison ${ }^{1}$
}

\section{Abstract}

The August 14, 2021, magnitude 7.2 Nippes, Haiti, earthquake triggered thousands of landslides on the Tiburon Peninsula. The landslides directly caused fatalities and damage and impeded response efforts by blocking roads and causing other infrastructure damage. Adverse effects of the landslides likely will continue for months to years. This report presents an assessment of potential postearthquake landslide-related geologic hazards for the Tiburon Peninsula and a preliminary map of the landslides triggered by the earthquake. This hazard assessment is based on an emergency analysis of the currently available, postearthquake satellite imagery. In this report, we highlight specific areas of concern that may benefit from more detailed assessment and longer-term monitoring. Our mapping efforts revealed that at least 4,893 landslides were triggered across the Tiburon Peninsula by the earthquake and subsequent rainfall from Tropical Cyclone Grace. We also observed hundreds of landslide deposits potentially restricting flow in rivers and streams. In addition, we observed landslides that likely affected roads by rendering them impassable or susceptible to subsequent damage from existing landslides. Because of the preliminary nature of this report and the limits of remote analyses, additional investigation and monitoring would be beneficial to accurately determine the threat posed by these hazards to people and infrastructure.

\section{Introduction}

The magnitude $(M) 7.2$ Nippes, Haiti, earthquake occurred at 12:29:08 coordinated universal time (08:29:08 local time) on August 14, 2021. The rupture started in the center of the Tiburon Peninsula, about 125 kilometers $(\mathrm{km})$ west of the capital, Port-au-Prince, and ruptured primarily westward with reverse and left-lateral strike-slip motion along

\footnotetext{
${ }^{1}$ U.S. Geological Survey

${ }^{2}$ U.S. Agency for International Development, Bureau for Humanitarian Assistance
}

the Enriquillo-Plantain Garden fault zone. The fault rupture terminated in the vicinity of Pic Macaya National Park. Shaking was estimated by the U.S. Geologial Survey (USGS) ShakeMap (ver. 14) to have exceeded $0.5 \mathrm{~g}$ (acceleration of gravity) along an $80-\mathrm{km}$ band of steep and rugged, and therefore landslide-susceptible, terrain in the center of the Tiburon Peninsula (fig. 1). The USGS near-real-time ground failure product (Allstadt and others, 2021) estimated that the landslides triggered by the Nippes earthquake would be significant in number and (or) spatial extent (estimated at about 70 square kilometers) and that the number of people living near landslide hazards was significant (estimated at about 9,000 people). The landslide probability map produced by the ground failure product is shown in figure 1 . The earthquake was followed by Tropical Cyclone Grace, which was estimated to have dropped 5-10 inches of rain in Haiti on August 16, 2021 (National Oceanic and Atmospheric Administration, 2021), and likely triggered additional landslides. More information about the earthquake, including the near-real-time products, is available from the USGS earthquake event page at https://earthquake .usgs.gov/earthquakes/eventpage/us6000f65h/executive.

During the week following the earthquake, a team of USGS scientists rapidly mapped landslides using remote methods and created a landslide inventory. By the end of this effort, 3,625 landslides had been mapped. This inventory, with critical daily observations, was shared with the U.S. Agency for International Development's (USAID's) Disaster Assistance Response Team (DART) and Response Management Team (RMT) for situational awareness and emergency response. The inventory also was made publicly available as an ArcGIS online web map for use by humanitarian aid organizations for situational awareness and emergency response. The original rapid inventory that was available immediately after the earthquake for situational awareness only is now superseded by the inventory associated with this report (Martinez and others, 2021).

For this report, we mapped additional landslides that were missed in the initial inventory. We carefully reviewed the inventory in its entirety to identify landslides that may pose ongoing threats to people and property (fig. 2). We mapped, as best as possible, the location of each landslide's headscarp area as a point feature. Some mapped locations may be 


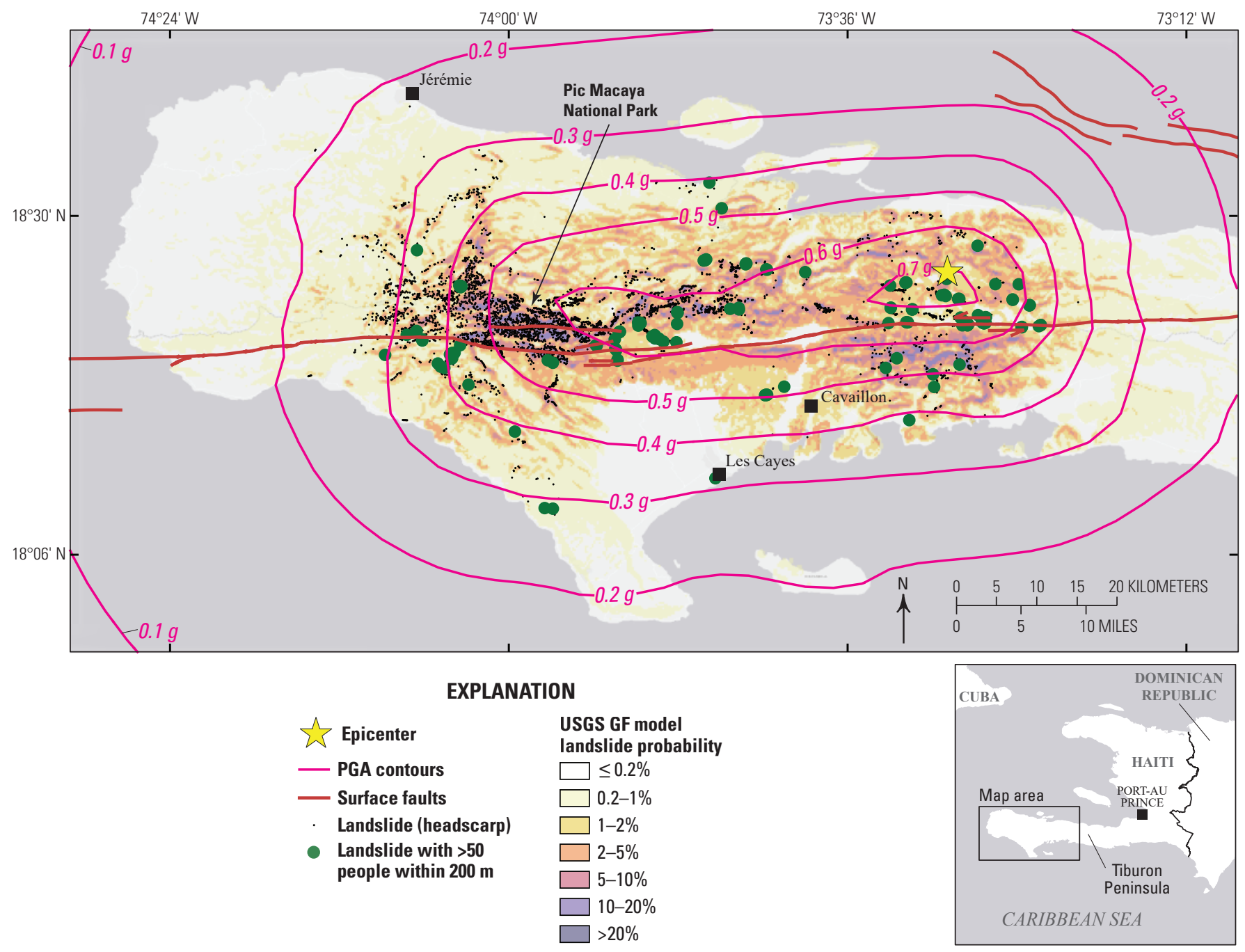

Figure 1. Overview of the Tiburon Peninsula showing contours of estimated peak ground acceleration (PGA) for the 2021 Nippes, Haiti, earthquake from the U.S. Geological Survey (USGS) ShakeMap (ver. 14) overlain on the USGS Ground Failure (GF) product landslide probability model (ver. 13). The landslide probability model provides an estimate of areas where earthquake-triggered landslides were most likely to have occurred, based on the ShakeMap shaking estimates. The model is intended primarily for near-real-time use and is available at https://earthquake.usgs.gov/earthquakes/eventpage/us6000f65h/ground-failure/summary. Black dots show headscarp locations of mapped landslides. Green dots show where human effects may have occurred because population estimates within a 200-meter radius of a given landslide exceeded 50 people. The earthquake ruptured primarily from east to west, starting at the epicenter (yellow star). Red lines indicate location of known faults in the region from Saint Fleur and others, 2020. N, north; W, west; $\mathrm{g}$, acceleration of gravity; $>$, greater than; $\mathrm{m}$, meter; $\leq$, less than or equal to; $\%$, percent.

imprecise because of the poor orthorectification of some of the satellite imagery used. Landslide polygons were not mapped for this preliminary version of the inventory. Most imagery available for the affected area was obtained after the passage of Tropical Cyclone Grace; thus, the landslide inventory presented could contain both earthquake- and rainfall-triggered landslides. However, we did not see many landslides with characteristics common to rainfall-triggered landslides, such as channelized flows, so we think that most of the landslides were triggered by the earthquake.
In addition to landslide headscarp locations, we present an assessment of potential postearthquake landslide-related geologic hazards for the Tiburon Peninsula. We highlight specific areas of concern that may benefit from more detailed assessment and longer-term monitoring because of the potential effects on people and infrastructure. Potential postearthquake landslide hazards include (1) sudden flooding from the failure of landslide dams; (2) continued landsliding of damaged slopes, especially along roads and river channels; (3) an overall increase in landslide activity for multiple years; and (4) changes in river behavior from an influx of landslide sediment that can lead to long-term changes in flooding risks. 


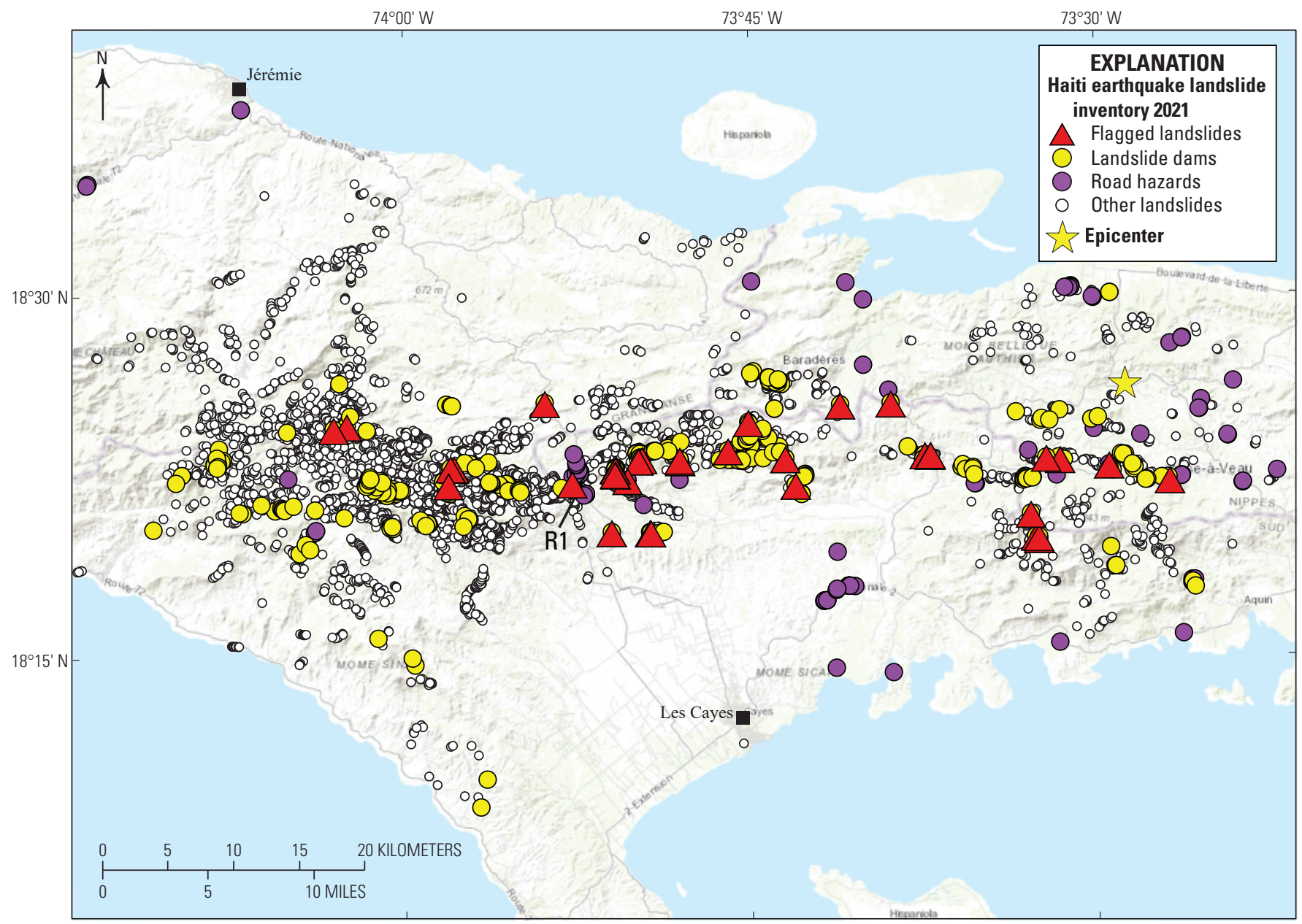

Esri, HERE Technologies, Garmin, U.S. Geological Survey, National Geospatial-Intelligence Agency

Figure 2. Overview map of the 2021 Nippes, Haiti, earthquake landslide inventory showing landslide dams, road hazards, and flagged landslides detailed in table 1. The location of a series of landslides along Route Nationale 7 is labeled as R1 in the figure (R1 in table 1) as they occurred along the main highway connecting Les Cayes and Jérémie. Flagged landslides may pose a particular hazard to people and structures and may benefit from additional study and monitoring. The western part of the study area lacked sufficient high-resolution imagery, so smaller landslide dams and channel obstructions may not have been fully identified or mapped. N, north; W, west.

As this event shows, earthquakes can set in motion a cascade of geologic events that can affect the landscape for months (or years) following an event (Fan and others, 2019). For example, in March of 2010, months after an M7.0 earthquake in Haiti, heavy rainfall led to flooding in Les Cayes and Cavaillon (United Nation's Children's Fund, 2010), which resulted in mass evacuations and the deaths of eight people. The flooding was attributed to the lack of drainage from canals blocked by earthquake debris. The March 2010 event illustrates the continued effect that an earthquake can have on a landscape. It also highlights the importance of continued monitoring and additional field investigations because heavy rainfall may, in the coming months, lead to increased hazards in Haiti following the 2021 earthquake.

\section{Data and Analysis}

To map the landslides, we used mid- to high-resolution satellite imagery including Sentinel-2 (10-meter [m] resolution), WorldView (0.3-0.5-m resolution), Planet (2.7-4.0-m resolution), and a high-resolution (1.5-m) digital elevation model (DEM) that was derived from light detection and ranging (lidar) collected from 2014 to 2016 (HaitiData and The World Bank, 2021). Postearthquake images were compared with pre-earthquake images to ensure the landslide feature was caused by the earthquake or the cyclone. The positional accuracy of satellite imagery can vary, especially in hilly areas or when using low-resolution imagery. Because of the varying quality of imagery used and our rapid mapping for the response, we estimate our accuracy of landslide headscarp points to be within tens of meters of each landslide. In many 
cases, when using poorly orthorectified images, we adjusted the location using the high-resolution DEM. For one of our more poorly orthorectified images, the root mean square error was calculated to be $45 \mathrm{~m}$. This error is not representative of all images used, but it provides an upper limit on the positional accuracy of our landslide mapping. As there was a large quantity of images utilized in our rapid mapping effort, a formal and systematic assessment on the positional accuracy of the data has yet to be completed.

To determine the potential for human and infrastructure effects, we referenced a grid of population data from the Facebook Connectivity Lab and Center for International Earth Science Information Network (2016) and OpenStreetMap (2021). The OpenStreetMap layer displays the locations of roads, rivers, and buildings. Specific hazards identified in our study include landslide dams and roads undercut or covered by landslide debris. We flagged landslides that appeared to present an immediate hazard to people or structures. Detailed descriptions of these flagged features and locations can be found in table 1. Corresponding satellite images of those flagged features can be seen in figures 3-7. Each figure contains flagged landslides from the same general geographic region. The corresponding details in the table for each feature can be referenced using the figure number column in table 1 . The inventory described in this report includes 4,893 landslides. The inventory remains preliminary, however, because it has not been thoroughly reviewed and high-resolution imagery remains unavailable in some areas. Additionally, there are a few localized areas in our mapping area that did not have cloud-free imagery.

\section{Coseismic Landslides}

The most intense landsliding occurred at the western end of the fault, where the terrain is most rugged, especially in the Pic Macaya National Park (fig. 1). Areas toward which the fault rupture is directed can experience a directivity pulse of higher ground motions (for example, Somerville and others, 1997) and therefore may be an additional factor explaining the high landslide concentration in the western end of the fault. However, landslides occurred along the entire length of the rupture, especially along steep channels and road cuts. A majority (95 percent) of the mapped landslides were triggered in calcareous geologic units, based on the geologic map from the Bureau des Mines et de l'Énergie (2005), whereas only 2.8 percent were triggered in alluvium and 2.1 percent in volcanic units.

Most landslides were in remote areas, although many were close to small human settlements. The green dots in figure 1 indicate landslides that have an estimated population of more than 50 people within a $200-\mathrm{m}$ radius. This analysis serves as a proxy for where effects to people were most likely to have occurred. We cannot discern the effects to people from landslides in these locations using satellite imagery alone, but landslide fatalities were reported by the media (Fox, 2021; Washington Post, 2021).

Many roads were blocked by landslides, which hindered travel and the movement of humanitarian aid. Figure 2 shows some of the landslides likely to have affected roads, based on satellite imagery analysis. We noted 292 landslide dams that may have blocked or partially obstructed river channels as well (fig. 2), although in many cases interpretation of satellite imagery indicates water has been able to flow through or around these obstructions. We discuss these potential landslide dams in detail in the "Ongoing Hazards" section.

Simple models based on global data indicate that an $M 7.2$ crustal earthquake might trigger 5,000 to 11,000 landslides (Keefer, 2002; Malamud and others, 2004); our inventory is at the lower end of that range. However, these global estimates depend on the shaking distribution details and the terrain susceptibility.

Although it affected a different part of Haiti, the August 2021 earthquake was in terrain similar to the $M 7.0$ earthquake that occurred in Haiti on January 12, 2010 (https:// earthquake.usgs.gov/earthquakes/eventpage/usp $000 \mathrm{~h} 60 \mathrm{~h} /$ executive). Both were shallow crustal earthquakes having a combination of left-lateral strike-slip and reverse faulting, although the 2021 earthquake had a stronger reverse component than the 2010 earthquake. During the initial field reconnaissance period, 4,000 to 5,000 landslides were estimated to have been triggered by the 2010 earthquake (Jibson and Harp, 2011). This was revealed to be an underestimate because 23,000 landslides were later mapped using high-resolution satellite and aerial imagery (Harp and others, 2016). The landslides triggered by the 2010 earthquake were observed to have occurred primarily in steep drainages along rivers and within calcareous geologic units (Harp and others, 2016). This correlation is similar to what we observed for the 2021 event. Landslide dams and increased sedimentation also were observed after the 2010 event (Jibson and Harp, 2011; Harp and others, 2016). 
Table 1. Notable landslide dams and road obstructions after the 2021 Nippes, Haiti, earthquake.

[Notable landslide dams and road obstructions are shown by identification numbers that correspond to point features within the associated inventory available (Martinez and others, 2021). These notable features are also shown in figures 3-7 of this report. In some instances, quality of imagery used to display these features is limited by data availability. Coordinate locations correspond to the approximate location of flagged features. For the exact location of specific landslides, refer to Martinez and others (2021). Communes are a third-level administrative boundary in Haiti. Because of mapping uncertainty, reported distances in the table are approximate. km, kilometer; m, meter; N, north; no., number; RN-7, route Nationale 7; W, west]

\begin{tabular}{|c|c|c|c|c|c|}
\hline ID no. & Coordinates & Commune & Description & Threat & Figure no. \\
\hline $\begin{array}{l}\text { D2 } \\
\text { D3 }\end{array}$ & $\begin{array}{l}73.8475146^{\circ} \mathrm{W} \\
18.37674466^{\circ} \mathrm{N}\end{array}$ & Camp-Perrin & Landslide dams blocking river; water is pooling. & $\begin{array}{l}\text { These landslide dams are upstream }(0.2-0.4 \mathrm{~km}) \text { from a popu- } \\
\text { lated area with several structures adjacent to the river. }\end{array}$ & $3 A$ \\
\hline $\begin{array}{l}\text { D4 } \\
\text { D5 } \\
\text { D6 } \\
\text { D12 } \\
\text { D13 }\end{array}$ & $\begin{array}{l}73.8476736^{\circ} \mathrm{W} \\
18.3799054^{\circ} \mathrm{N}\end{array}$ & Camp-Perrin & Landslide dams with water pooling present. & $\begin{array}{l}\text { These landslide dams are upstream }(0.8 \mathrm{~km}) \text { from a populated } \\
\text { area with several structures adjacent to the river. }\end{array}$ & $3 A$ \\
\hline $\mathrm{R} 1$ & $\begin{array}{l}73.8788310^{\circ} \mathrm{W} \\
18.3703507^{\circ} \mathrm{N}\end{array}$ & Camp-Perrin & $\begin{array}{l}\text { A series of landslides along main road, RN-7, that } \\
\text { initially blocked this key route after the earthquake. } \\
\text { It has since been cleared (as observed in imagery), } \\
\text { but material will likely continue to move downslope } \\
\text { at this location. }\end{array}$ & $\begin{array}{l}\text { This is a main road that connects Les Cayes and Jérémie and } \\
\text { provides access to interior communities. }\end{array}$ & $3 B$ \\
\hline R7 & $\begin{array}{l}73.8387131^{\circ} \mathrm{W} \\
18.3719796^{\circ} \mathrm{N}\end{array}$ & Camp-Perrin & $\begin{array}{l}\text { Potentially deep landslide caused severe damage to a } \\
\text { road in a settled area. }\end{array}$ & $\begin{array}{l}\text { This poses an ongoing hazard to the road and access may be } \\
\text { limited in this area. }\end{array}$ & $3 C$ \\
\hline $\begin{array}{l}\text { D10 } \\
\text { D11 }\end{array}$ & $\begin{array}{l}73.8309072^{\circ} \mathrm{W} \\
18.3859385^{\circ} \mathrm{N}\end{array}$ & Camp-Perrin & $\begin{array}{l}\text { Two landslide dams blocked a drainage that appeared dry } \\
\text { at the time of the image, but a small amount of pooled } \\
\text { water is visible northeast of the easternmost dam. }\end{array}$ & $\begin{array}{l}\text { These landslide dams are } 3.5-\mathrm{km} \text { upstream from a populated } \\
\text { area and structures that are adjacent to river floodplain. }\end{array}$ & $3 D$ \\
\hline D27 & $\begin{array}{l}73.8495048^{\circ} \mathrm{W} \\
18.3369706^{\circ} \mathrm{N}\end{array}$ & Camp-Perrin & Landslide dam with visible pooling. & $\begin{array}{l}\text { Immediately upstream }(0.05 \mathrm{~km}) \text { from a populated area and } \\
\text { structures. This dam is of high concern because of its proxim- } \\
\text { ity to structures. }\end{array}$ & $3 E$ \\
\hline $\begin{array}{l}\text { D28 } \\
\text { D29 }\end{array}$ & $\begin{array}{l}73.8227571^{\circ} \mathrm{W} \\
18.3359879^{\circ} \mathrm{N}\end{array}$ & Camp-Perrin & Landside dam with visible pooling. & $\begin{array}{l}\text { This landslide dam is directly adjacent to a populated area and } \\
\text { several structures. }\end{array}$ & $3 F$ \\
\hline D24 & $\begin{array}{l}73.8996369^{\circ} \mathrm{W} \\
18.4269625^{\circ} \mathrm{N}\end{array}$ & Pestel & $\begin{array}{l}\text { Landslide dam blocking } 450 \mathrm{~m} \text { of the river channel. } \\
\text { Pool is about } 300 \mathrm{~m} \text { long and appears to be growing } \\
\text { in recent imagery. }\end{array}$ & $\begin{array}{l}\text { Scattered settlements downstream and along the river. River } \\
\text { drains into a closed basin or maybe a karst cavern. Adjacent } \\
\text { to RN-7, so there is likely awareness of the growing pool. }\end{array}$ & $4 A$ \\
\hline $\begin{array}{l}\text { D39 } \\
\text { D40 }\end{array}$ & $\begin{array}{l}73.9637699^{\circ} \mathrm{W} \\
18.3832639^{\circ} \mathrm{N}\end{array}$ & Beaumont & Landside dams with visible pooling. & $\begin{array}{l}\text { No densely populated areas or structures are downstream from } \\
\text { these dams. }\end{array}$ & $4 B$ \\
\hline D22 & $\begin{array}{l}73.9681267^{\circ} \mathrm{W} \\
18.3697023^{\circ} \mathrm{N}\end{array}$ & Chantal & $\begin{array}{l}\text { Landslide dams; unknown if they are completely or } \\
\text { partially blocking river. }\end{array}$ & $\begin{array}{l}\text { No populated area or structures are downstream from these } \\
\text { dams. }\end{array}$ & $4 C$ \\
\hline $\begin{array}{l}\text { D18 } \\
\text { D19 }\end{array}$ & $\begin{array}{l}74.0443117^{\circ} \mathrm{W} \\
18.4109764^{\circ} \mathrm{N}\end{array}$ & Roseaux & Landslide dams with pooling visible. & $\begin{array}{l}\text { No populated area or structures are downstream from these } \\
\text { dams. }\end{array}$ & $4 D$ \\
\hline
\end{tabular}


Table 1. Notable landslide dams and road obstructions after the 2021 Nippes, Haiti, earthquake.-Continued

[Notable landslide dams and road obstructions are shown by identification numbers that correspond to point features within the associated inventory available (Martinez and others, 2021). These notable features are also shown in figures 3-7 of this report. In some instances, quality of imagery used to display these features is limited by data availability. Coordinate locations correspond to the approximate location of flagged features. For the exact location of specific landslides, refer to Martinez and others (2021). Communes are a third-level administrative boundary in Haiti. Because of mapping uncertainty, reported distances in the table are approximate. km, kilometer; m, meter; $\mathrm{N}$, north; no., number; RN-7, route Nationale 7; W, west]

\begin{tabular}{|c|c|c|c|c|c|}
\hline ID no. & Coordinates & Commune & Description & Threat & Figure no. \\
\hline D8 & $\begin{array}{l}73.7247343^{\circ} \mathrm{W} \\
18.3867478^{\circ} \mathrm{N}\end{array}$ & Maniche & $\begin{array}{l}\text { Landslide dam with no pooling currently visible; water } \\
\text { is not clearly visible in the channel. }\end{array}$ & $\begin{array}{l}\text { This landslide dam is } 0.7-\mathrm{km} \text { upstream from a populated area } \\
\text { and structures that are adjacent to river floodplain. A road } \\
\text { parallels the river downstream. }\end{array}$ & $5 A$ \\
\hline D9 & $\begin{array}{l}73.7662063^{\circ} \mathrm{W} \\
18.3925709^{\circ} \mathrm{N}\end{array}$ & Maniche & $\begin{array}{l}\text { Landslide dam with no pooling currently visible, but } \\
\text { no water is visible in the channel at the time of the } \\
\text { image. Landslide is large but is close to the top of its } \\
\text { tributary, so less area can contribute water than for } \\
\text { some other dams. }\end{array}$ & $\begin{array}{l}\text { This landslide dam is 2.6-km upstream from a populated area } \\
\text { and structures that are adjacent to river floodplain. }\end{array}$ & $5 B$ \\
\hline D14 & $\begin{array}{l}73.7512845^{\circ} \mathrm{W} \\
18.4118467^{\circ} \mathrm{N}\end{array}$ & Maniche & $\begin{array}{l}\text { Landslide dam with no pooling currently visible; chan- } \\
\text { nel dry at time of the image. }\end{array}$ & $\begin{array}{l}\text { This landside dam is } 1.6-\mathrm{km} \text { upstream from a populated area } \\
\text { and structures that are adjacent to river floodplain. }\end{array}$ & $5 C$ \\
\hline $\begin{array}{l}\text { D16 } \\
\text { D17 }\end{array}$ & $\begin{array}{l}73.8011201^{\circ} \mathrm{W} \\
18.3864305^{\circ} \mathrm{N}\end{array}$ & Maniche & $\begin{array}{l}\text { Landslide dams with pooling visible behind the larger } \\
\text { dam. }\end{array}$ & $\begin{array}{l}\text { This landslide dam is directly adjacent to a populated area and } \\
\text { several structures. More populated regions are downstream. } \\
\text { Roads are adjacent to and intersect the river. }\end{array}$ & $5 D$ \\
\hline $\mathrm{R} 23$ & $\begin{array}{l}73.7172863^{\circ} \mathrm{W} \\
18.3685561^{\circ} \mathrm{N}\end{array}$ & Maniche & Partial landslide dam adjacent to road and river. & $\begin{array}{l}\text { Adjacent to road, which presents an ongoing road hazard. } \\
\text { Upstream }(1.6 \mathrm{~km}) \text { from a populated area adjacent to river. }\end{array}$ & $5 E$ \\
\hline D21 & $\begin{array}{l}73.5362199^{\circ} \mathrm{W} \\
18.3865591^{\circ} \mathrm{N}\end{array}$ & L'Asile & $\begin{array}{l}\text { Possible deep landside damming a stream with visible } \\
\text { pooling. }\end{array}$ & $\begin{array}{l}\text { This landside dam is } 3.5-\mathrm{km} \text { upstream from populated areas } \\
\text { and structures that are adjacent to Grand Rivière de Nippes } \\
\text { floodplain. }\end{array}$ & $6 A$ \\
\hline D25 & $\begin{array}{l}73.5479989^{\circ} \mathrm{W} \\
18.3475403^{\circ} \mathrm{N}\end{array}$ & L'Asile & $\begin{array}{l}\text { Landslide dam; unknown if the dam is completely or } \\
\text { partially blocking river channel. }\end{array}$ & Upstream $(1.6-2 \mathrm{~km})$ from clusters of structures. & $6 B$ \\
\hline D37 & $\begin{array}{l}73.4468978^{\circ} \mathrm{W} \\
18.3712835^{\circ} \mathrm{N}\end{array}$ & L'Asile & $\begin{array}{l}\text { Landslide dam; unknown if the dam is completely or } \\
\text { partially blocking river, but some pooling is visible. }\end{array}$ & $\begin{array}{l}\text { Directly upstream from roads }(0.4-0.7 \mathrm{~km}) \text { that intersect river } \\
\text { and upstream }(1.2 \mathrm{~km}) \text { from populated areas with structures } \\
\text { adjacent to river. }\end{array}$ & $6 C$ \\
\hline D41 & $\begin{array}{l}73.5263153^{\circ} \mathrm{W} \\
18.3857851^{\circ} \mathrm{N}\end{array}$ & L'Asile & $\begin{array}{l}\text { Landside dam with visible pooling but not complete } \\
\text { restriction of flow. }\end{array}$ & Upstream $(3 \mathrm{~km})$ from clusters of structures. & $6 D$ \\
\hline R42 & $\begin{array}{l}73.4908007^{\circ} \mathrm{W} \\
18.3811946^{\circ} \mathrm{N}\end{array}$ & L'Asile & $\begin{array}{l}\text { Potential road damage from landslide; would need } \\
\text { higher resolution imagery to confirm. }\end{array}$ & Potential ongoing road hazard. & $6 E$ \\
\hline D26 & $\begin{array}{l}73.6485411^{\circ} \mathrm{W} \\
18.4249629^{\circ} \mathrm{N}\end{array}$ & Cavaillon & $\begin{array}{l}\text { Landslide dam; unknown if the dam is completely or } \\
\text { partially blocking river channel. }\end{array}$ & Upstream $(0.6 \mathrm{~km})$ from clusters of structures and a road. & $7 A$ \\
\hline $\begin{array}{l}\text { D30 } \\
\text { D31 } \\
\text { D32 }\end{array}$ & $\begin{array}{l}73.5438633^{\circ} \mathrm{W} \\
18.3318873^{\circ} \mathrm{N}\end{array}$ & Saint Louis du Sud & $\begin{array}{l}\text { Landslide dams; unknown if dams are completely or } \\
\text { partially blocking river channel. }\end{array}$ & Upstream $(0.7 \mathrm{~km})$ from a cluster of structures. & $7 B$ \\
\hline
\end{tabular}


Table 1. Notable landslide dams and road obstructions after the 2021 Nippes, Haiti, earthquake.—Continued

[Notable landslide dams and road obstructions are shown by identification numbers that correspond to point features within the associated inventory available (Martinez and others, 2021). These notable features are also shown in figures 3-7 of this report. In some instances, quality of imagery used to display these features is limited by data availability. Coordinate locations correspond to the approximate location of flagged features. For the exact location of specific landslides, refer to Martinez and others (2021). Communes are a third-level administrative boundary in Haiti. Because of mapping uncertainty, reported distances in the table are approximate. km, kilometer; m, meter; N, north; no., number; RN-7, route Nationale 7; W, west]

\begin{tabular}{|c|c|c|c|c|c|}
\hline ID no. & Coordinates & Commune & Description & Threat & Figure no. \\
\hline $\begin{array}{l}\text { D33 } \\
\text { D34 } \\
\text { D35 }\end{array}$ & $\begin{array}{l}73.6196799^{\circ} \mathrm{W} \\
18.3886041^{\circ} \mathrm{N}\end{array}$ & Cavaillon & Landside dams with visible pooling. & Upstream $(3.5 \mathrm{~km})$ from clusters of structures and a road. & $7 C$ \\
\hline D36 & $\begin{array}{l}73.6237611^{\circ} \mathrm{W} \\
18.3887233^{\circ} \mathrm{N}\end{array}$ & Cavaillon & Landside dam with visible pooling. & Upstream $(2 \mathrm{~km})$ from clusters of structures and a road. & $7 D$ \\
\hline D38 & $\begin{array}{l}73.6848976^{\circ} \mathrm{W} \\
18.4241081^{\circ} \mathrm{N}\end{array}$ & Baradères & $\begin{array}{l}\text { Landslide dam; unknown if the dam is completely or } \\
\text { partially blocking river. }\end{array}$ & $\begin{array}{l}\text { Upstream }(1.4 \mathrm{~km}) \text { from densely populated areas and structures. } \\
\text { Also upstream from roads that are adjacent to and intersect } \\
\text { the river channel farther downstream. }\end{array}$ & $7 E$ \\
\hline
\end{tabular}


A

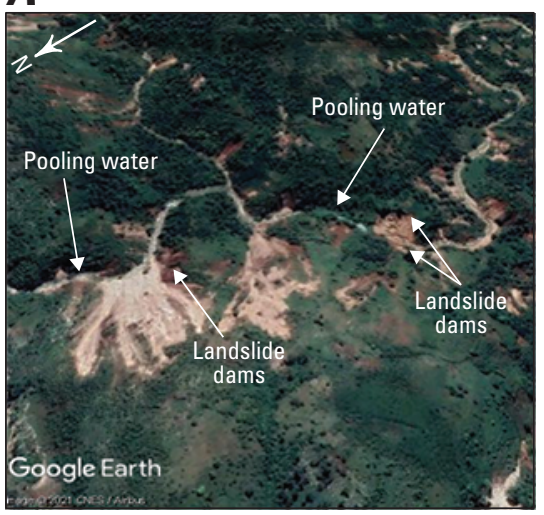

Image (c) 2021 CNES/ Airbus $0 \quad 100200300$ METERS Imagery Date: 08/27/2021

$0300600 \quad 900$ FEET

D

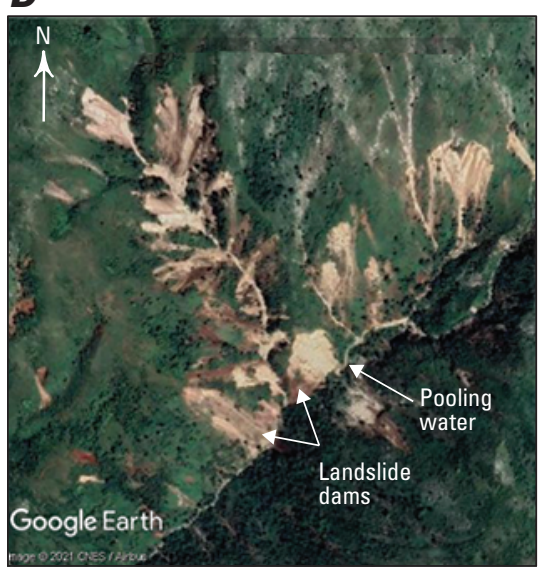

Image (C) 2021 CNES/ Airbus $0 \quad 100200300$ METERS Imagery Date: 08/27/2021

$0300 \quad 600 \quad 900$ FEET
B

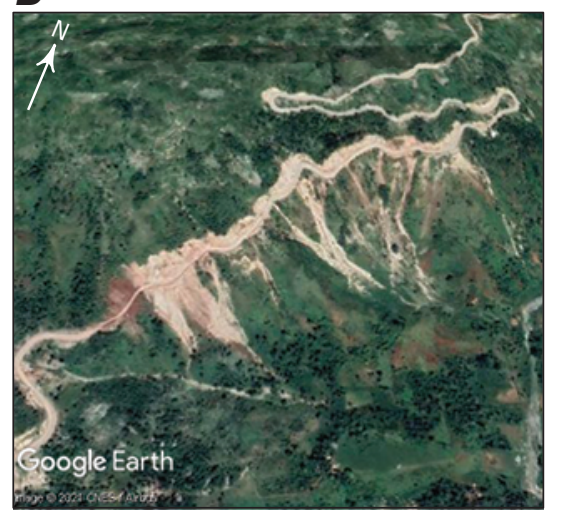

Image () 2021 CNES/ Airbus $0 \quad 200 \quad 400$ METERS Imagery Date: 08/27/2021

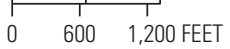

$\boldsymbol{E}$

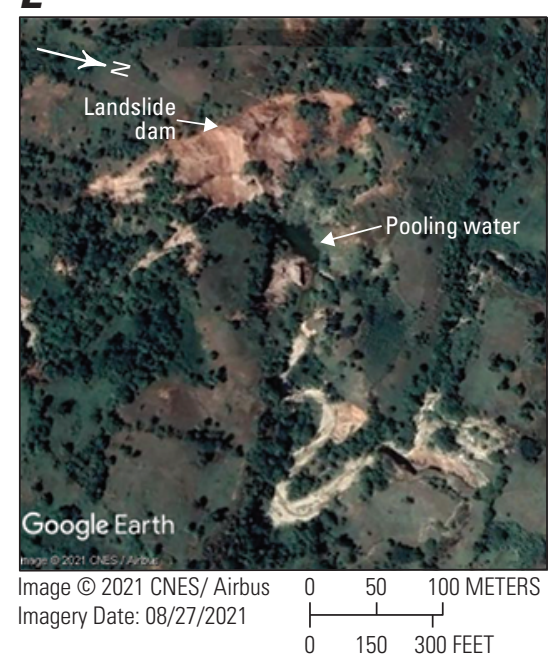

C

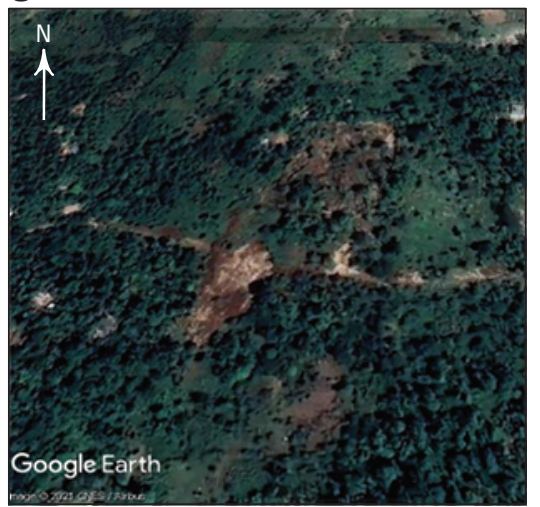

Image (c) 2021 CNES/ Airbus $0 \quad 50 \quad 100150$ METERS Imagery Date: 08/27/2021

$0 \quad 150300 \begin{array}{lll}1 & 450 \text { FEET }\end{array}$

$\boldsymbol{F}$

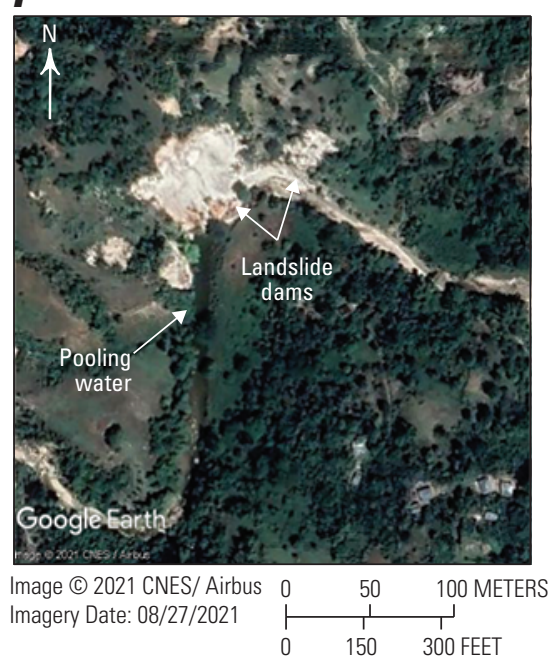

Figure 3. Flagged landslide features in Camp-Perrin commune, identified from satellite imagery after the 2021 Nippes, Haiti, earthquake. Refer to table 1 for coordinates to locate features. A, Seven landslide dams along a river bank and upstream (0.2-0.8 kilometers [km]) from a populated area with several structures adjacent to the river. Landslide dams resulted in two pools of water. River is flowing to the south. $B$, A series of landslides along main road Route Nationale 7 (RN-7) that initially blocked this route after the earthquake. $C$, A potentially deep landslide (sliding surface of the landslide is several meters below the ground surface) that has caused severe damage to a road in a settled area. This landslide poses an ongoing hazard to the road; access may be limited in this area. $D$, Two landslide dams blocking a drainage that appeared dry at the time of the image. A small amount of pooled water is present to the northeast of the easternmost dam. River is flowing to the southwest. These landslide dams are 3.5-km upstream from a populated area and structures that are adjacent to river floodplain. $E$, Landslide dam with visible pooling immediately upstream $(0.05 \mathrm{~km})$ from a populated area and structures; dam is of high concern because of proximity to structures. River is flowing to the south. $F$, Landslide dam with visible pooling directly adjacent to a populated area and several structures. River is flowing to the north. N, north; CNES, Centre National d`études Spatiales. 

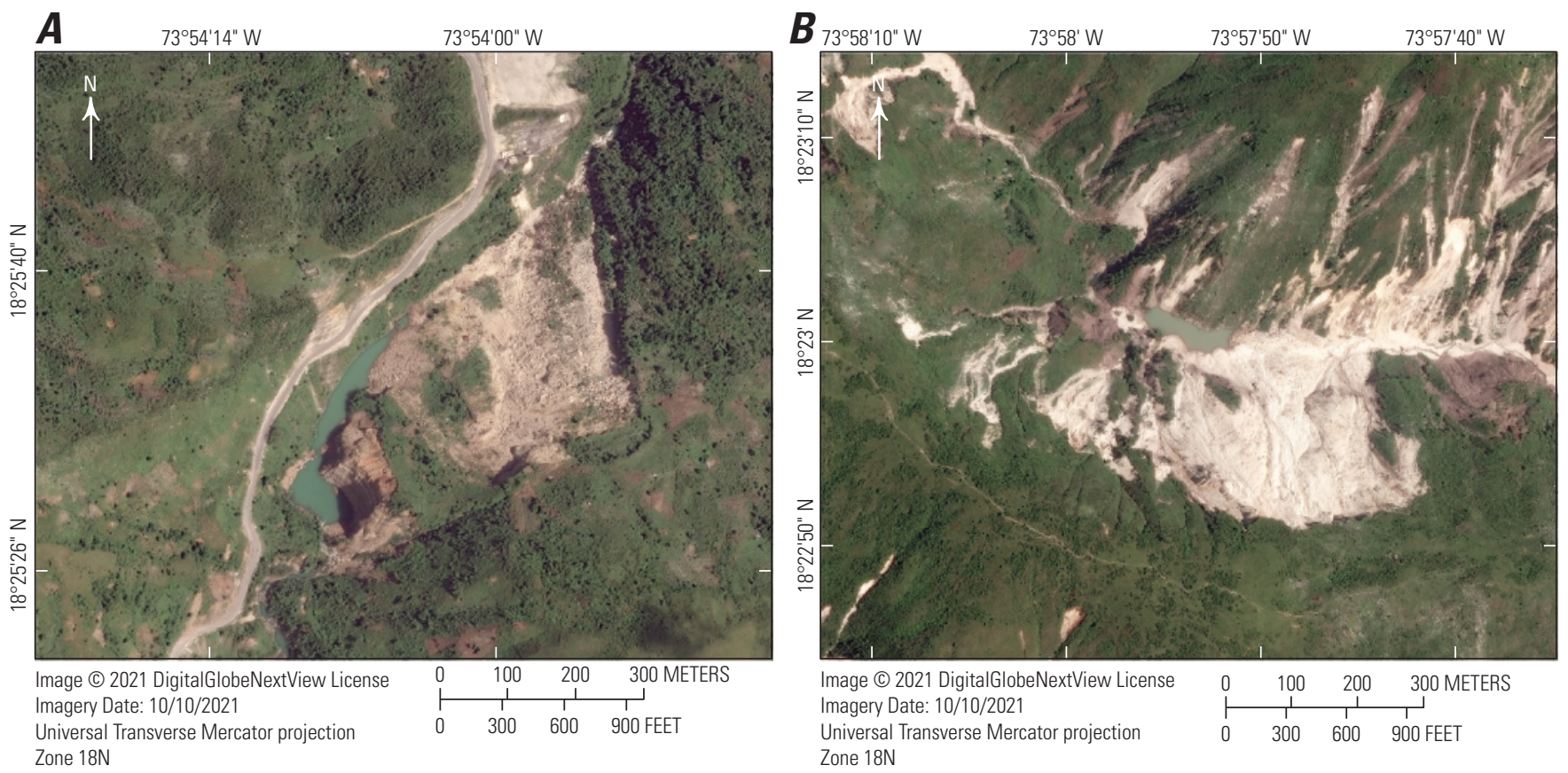

World Geodetic System of 1984 Zone $18 \mathrm{~N}$
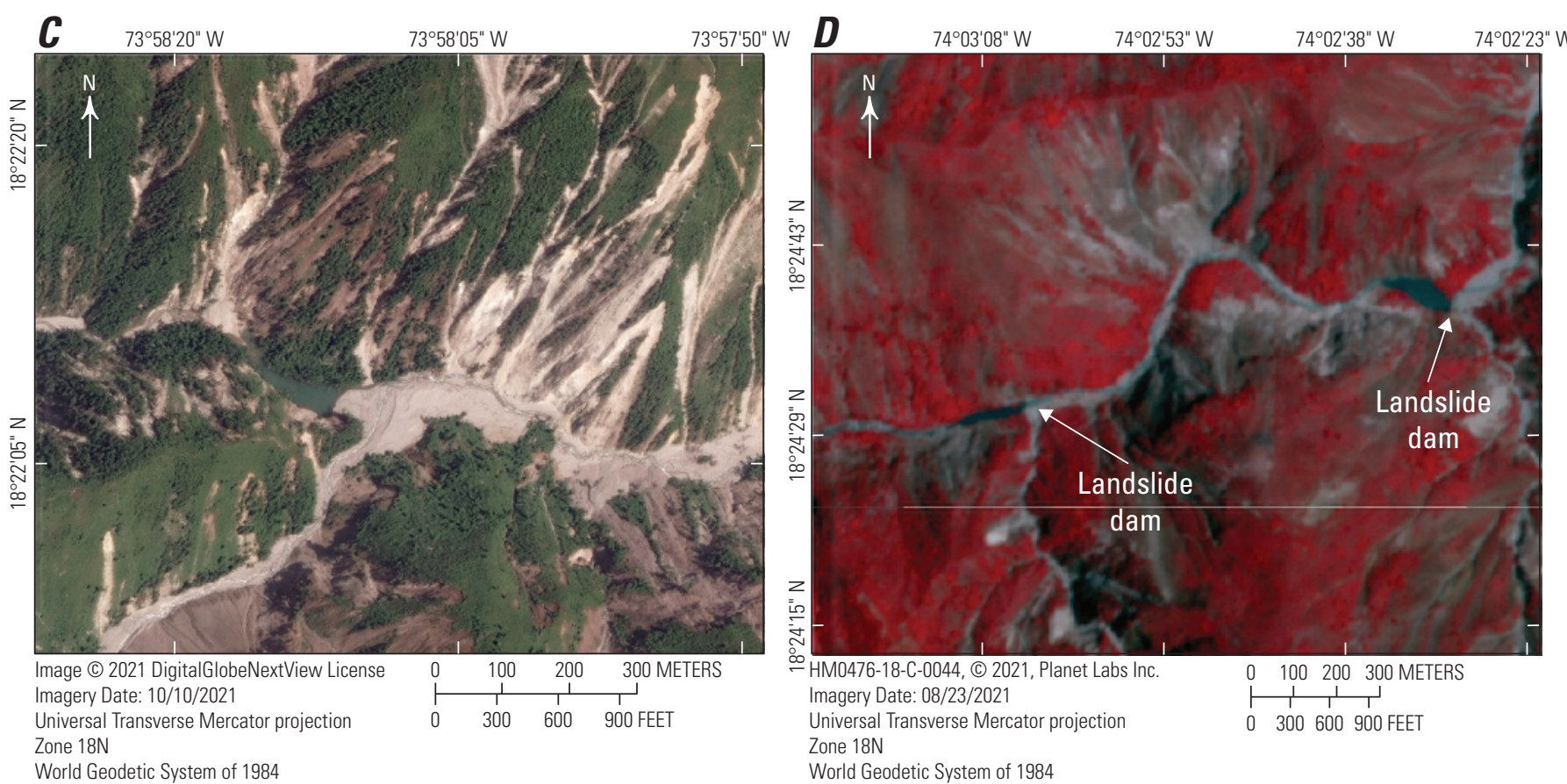

Figure 4. Flagged landslide features in Pestel, Beaumont, Chantal, and Roseaux communes, identified from satellite imagery after the 2021 Nippes, Haiti, earthquake. Refer to table 1 for coordinates to locate features. A, Landslide dam blocking 450 meters of the river channel; pool is about 300 meters long and appears to be growing in recent imagery. There are scattered settlements downstream and along the river. River drains into a closed basin or maybe a karst cavern. This feature is adjacent to Route Nationale 7 (RN-7), so there is likely awareness of the growing pool. River is flowing to the northeast. $B$, Landside dams with visible pooling; no densely populated areas or structures are downstream from these dams. River is flowing to the east. $C$, Landslide dams are visible; unknown if dams are completely or partially blocking the river; no populated area or structures are downstream from these dams. River is flowing to the east. $D$, Two landslide dams with visible pooling. Feature is shown using a false color infrared image, which was used in this instance because image bands needed to create false color images are available for this area. The landslides and resultant pooling are also more easily discernible in false color particularly in cases where image resolution is low. Quality of imagery is limited by data availability. White arrows point to the dams restricting the flow of water. River is flowing to the east. N, north; W, west. 
$A$

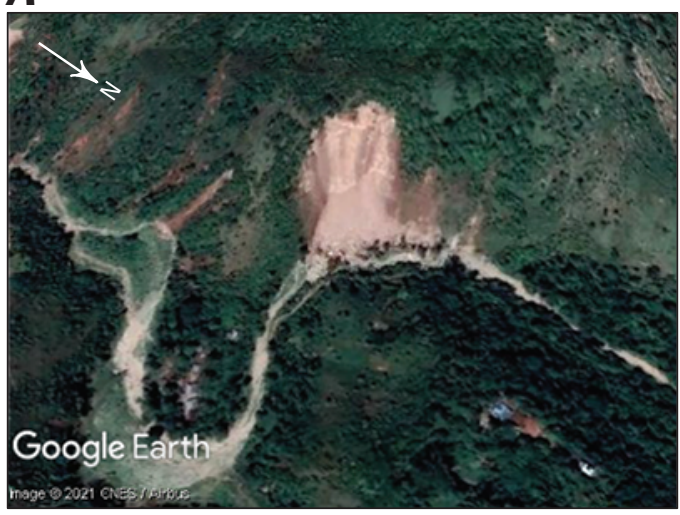

Image (C) 2021 CNES/ Airbus Imagery Date: 08/27/2021

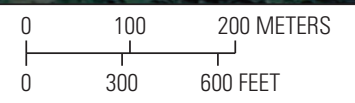

C

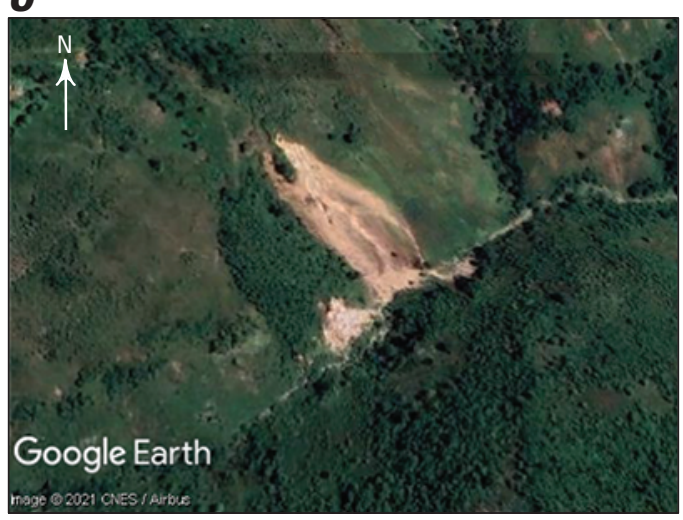

Image (C) 2021 CNES/ Airbus Imagery Date: 08/27/2021

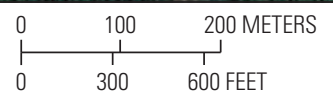

E

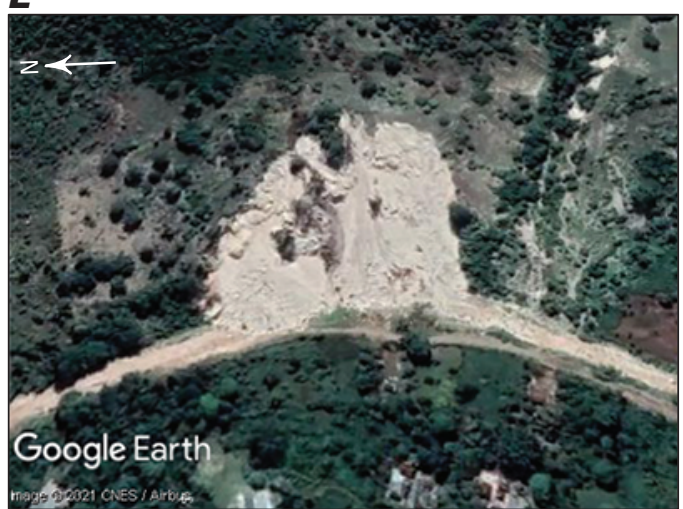

Image (C) 2021 CNES/ Airbus

Imagery Date: 08/27/2021
$\boldsymbol{B}$

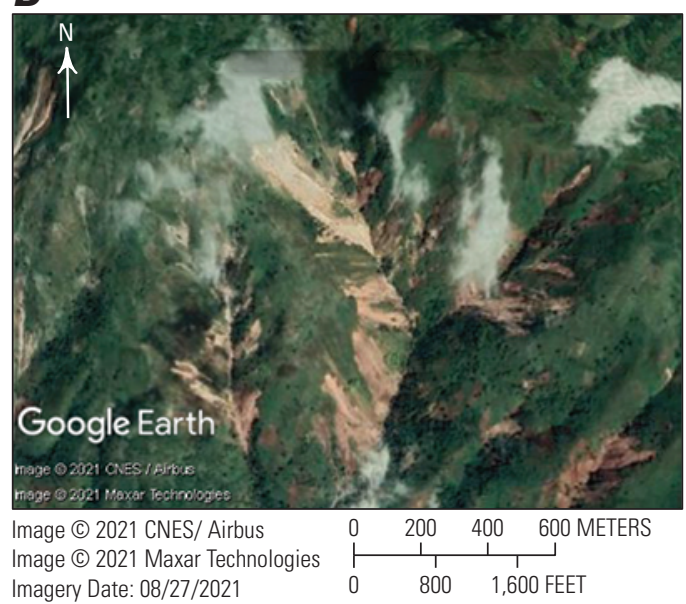

D

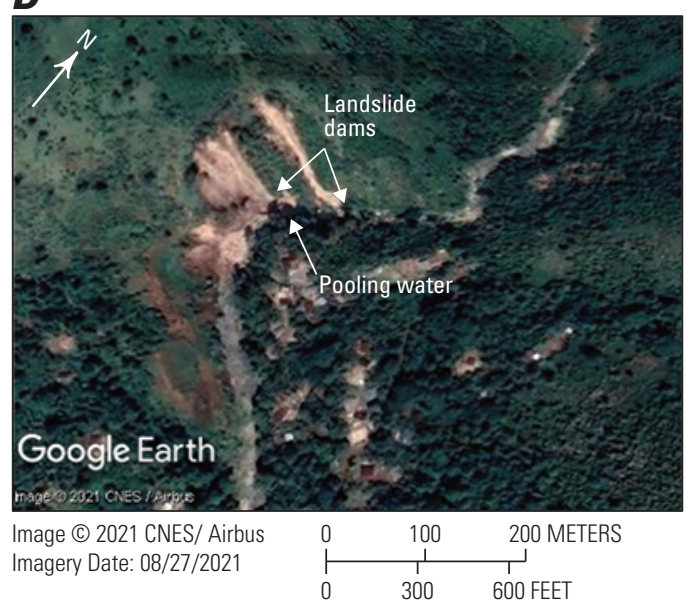

Figure 5. Flagged landslide features in Maniche commune, identified from satellite imagery after the 2021 Nippes, Haiti, earthquake. Refer to table 1 for coordinates to locate features. $A$, Landslide dam with no pooling currently visible; water is not clearly visible in the channel; 0.7 -kilometers $(\mathrm{km})$ upstream from a populated area and structures that are adjacent to river floodplain; a road parallels the river downstream. $B$, Landslide dam with no pooling currently visible but no water visible in the channel at the time of the image. Landslide is large but is close to the top of its tributary and so less area can contribute water than for some other dams. The landslides shown here are 2.6-km upstream from a populated area and structures that are adjacent to river floodplain. Clouds obscure a portion of the imagery. $C$, Landslide dam with no pooling currently visible; channel dry at time of the image. This landside dam is 1.6-km upstream from a populated area and structures that are adjacent to river floodplain. $D$, Two landslide dams with pooling visible behind the larger dam. River is flowing to the south. $E$, Partial landslide dam adjacent to river and road, which presents an ongoing hazard; upstream $(1.6 \mathrm{~km})$ from a populated area adjacent to river. N, north; CNES, Centre National d études Spatiales. 

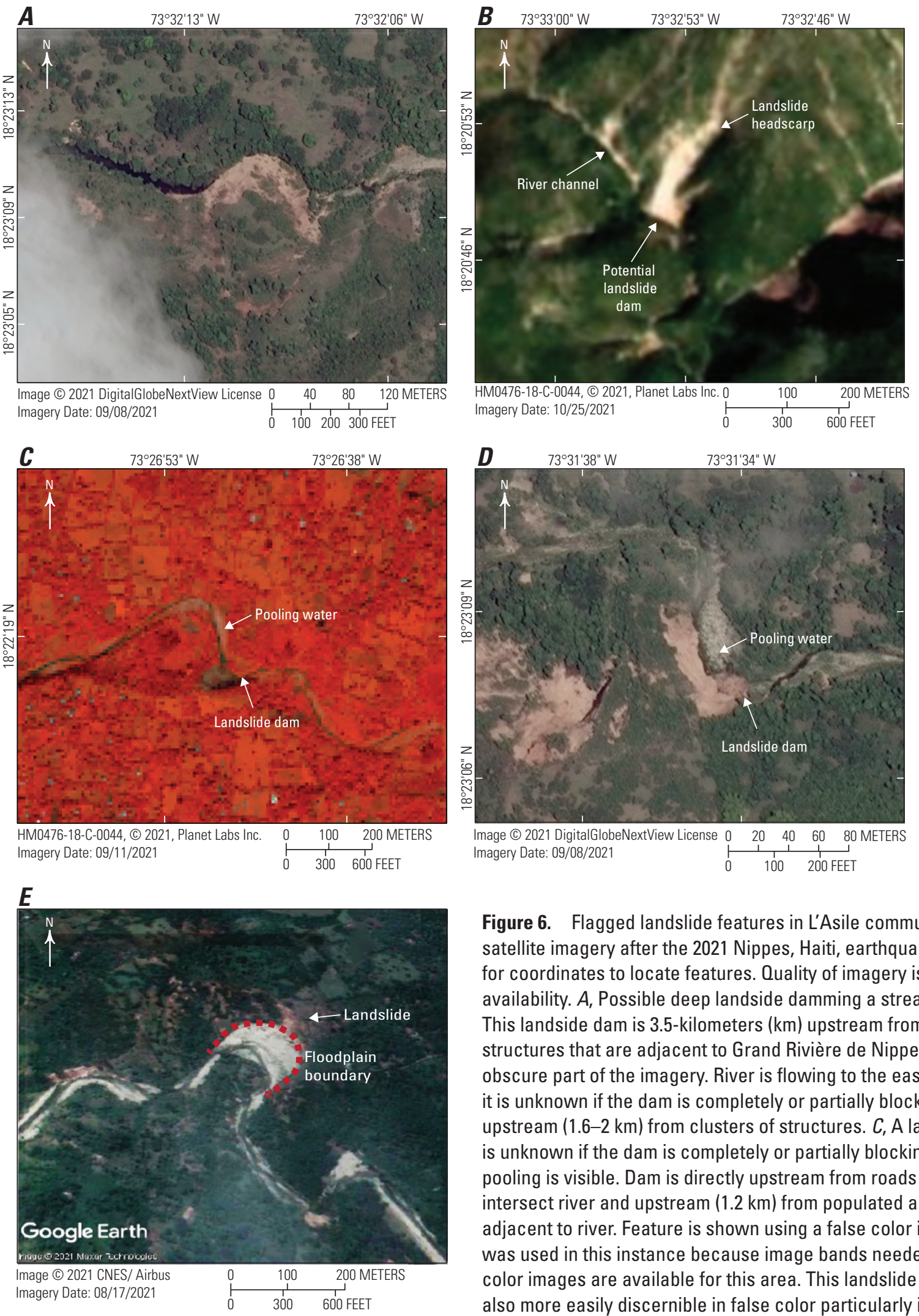

Figure 6. Flagged landslide features in L'Asile commune, identified from satellite imagery after the 2021 Nippes, Haiti, earthquake. Refer to table 1 for coordinates to locate features. Quality of imagery is limited by data availability. $A$, Possible deep landside damming a stream with visible pooling. This landside dam is 3.5-kilometers $(\mathrm{km})$ upstream from populated areas and structures that are adjacent to Grand Rivière de Nippes floodplain. Clouds obscure part of the imagery. River is flowing to the east. $B, A$ landslide dam; it is unknown if the dam is completely or partially blocking river channel; upstream (1.6-2 km) from clusters of structures. $C_{r}$ A landslide dam; it is unknown if the dam is completely or partially blocking river, but some pooling is visible. Dam is directly upstream from roads $(0.4-0.7 \mathrm{~km})$ that intersect river and upstream $(1.2 \mathrm{~km})$ from populated areas with structures adjacent to river. Feature is shown using a false color infrared image, which was used in this instance because image bands needed to create false color images are available for this area. This landslide dam and pooling are also more easily discernible in false color particularly in cases where image resolution is low. $D, A$ landside dam with visible pooling but not complete restriction of flow. The dam is upstream $(3 \mathrm{~km})$ from clusters of structures. River is flowing to the east. $E$, Potential road damage from landslide near the landslide headscarp; need higher resolution imagery to confirm. Potential ongoing road hazard as the landslide may continue to retreat towards road. $\mathrm{N}$, north; W, west. 

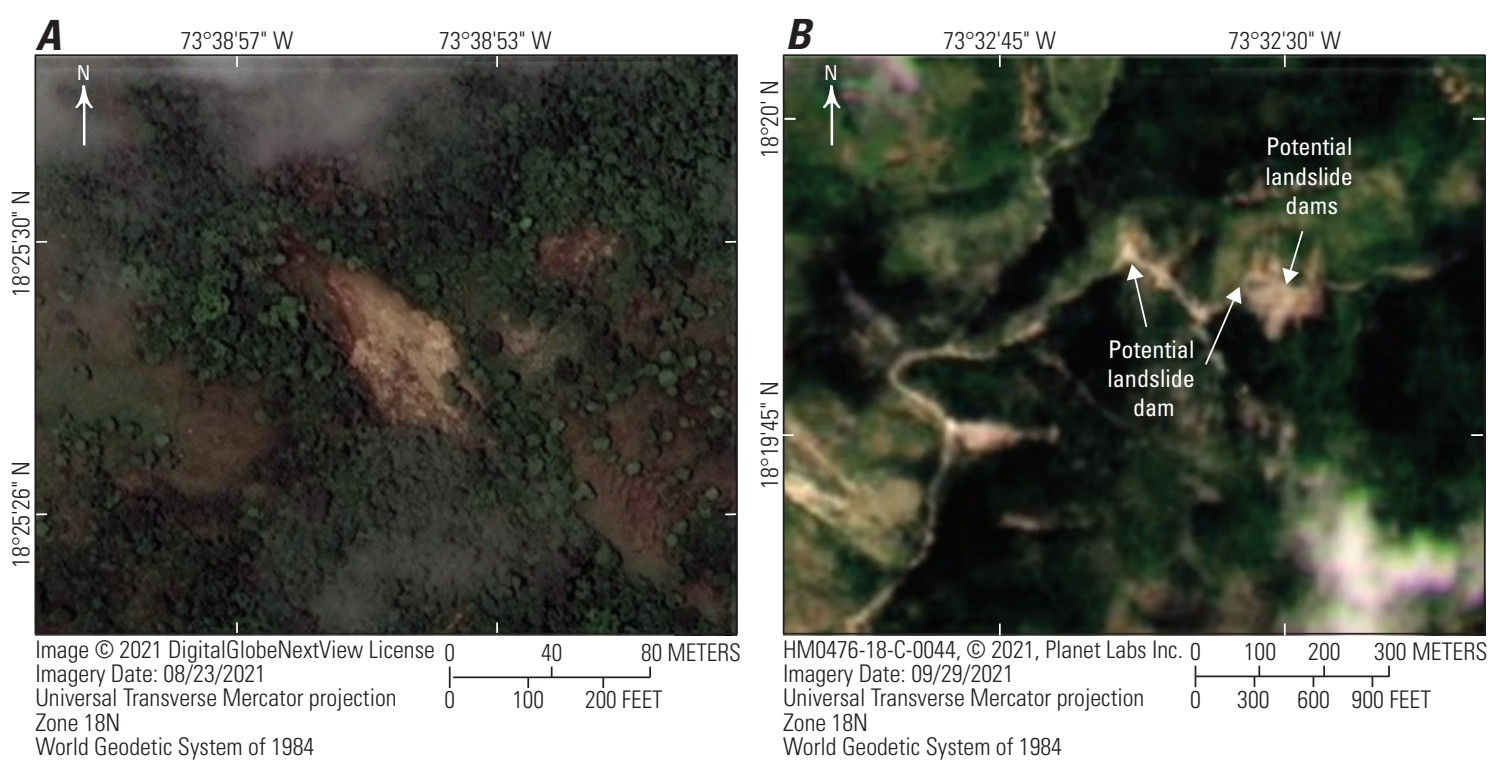

C

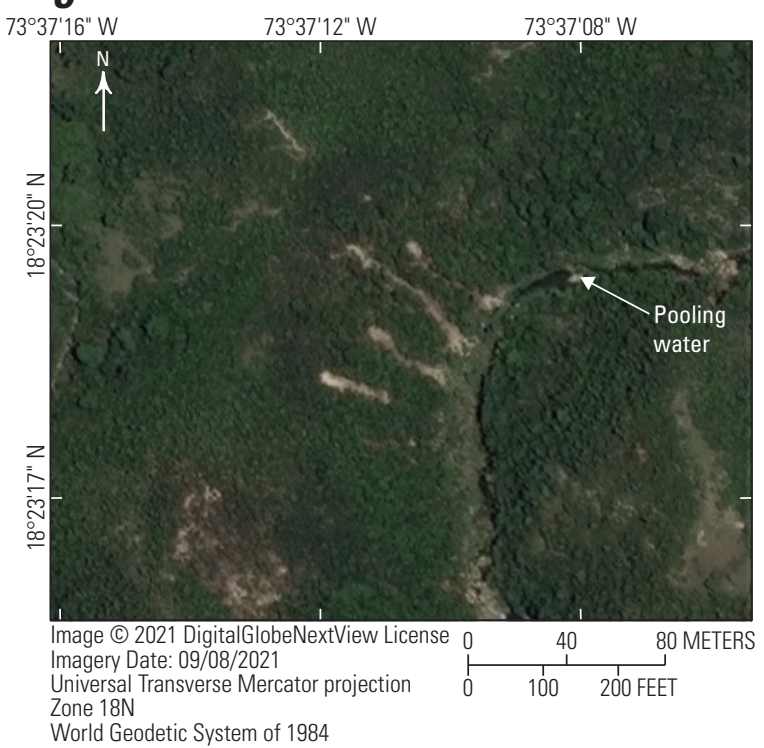

$\boldsymbol{E}$

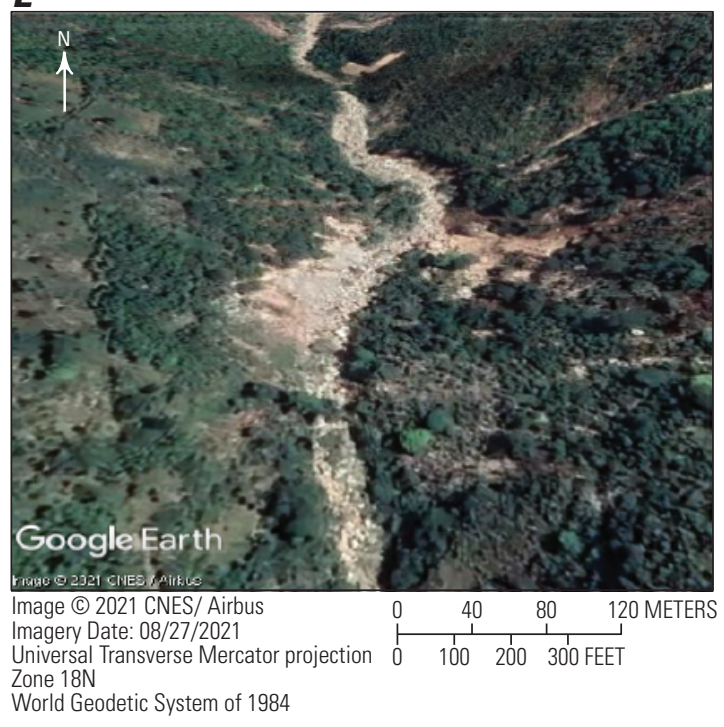

D

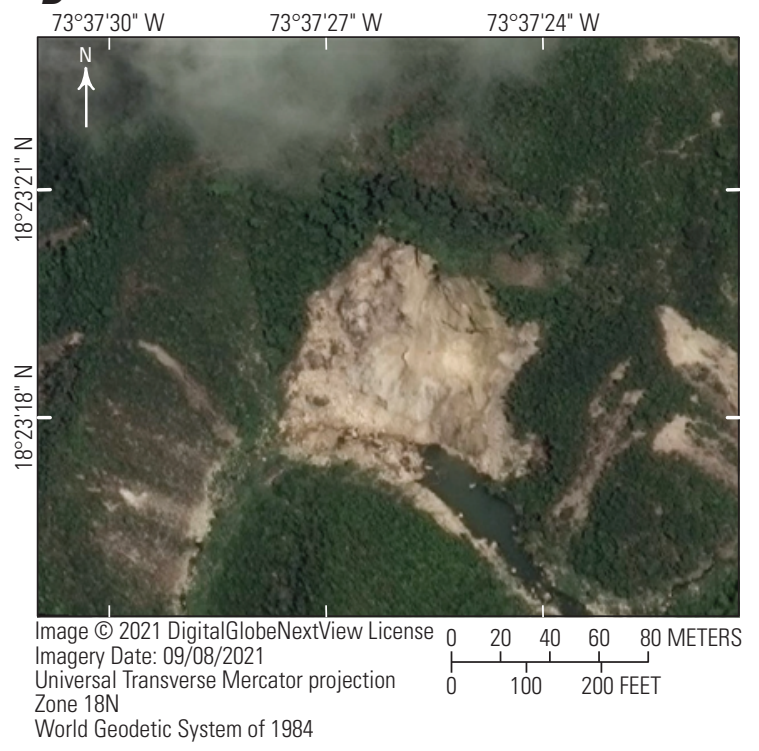

Figure 7. Flagged landslides in Cavaillon, Saint Louis du Sud, and Baradères communes, identified from satellite imagery after the 2021 Nippes, Haiti, earthquake. Refer to table 1 for coordinates to locate features. Clouds obscure a portion of the imagery in panels $A, B$, and $D$. $A$, Landslide dam; unknown if the dam is completely or partially blocking the narrow river channel. The dam is upstream (0.6 kilometers [km]) from clusters of structures and a road. $B$, Three landslide dams; unknown if dams are completely or partially blocking river channel. Quality of imagery is limited by data availability. White arrows point to the potential landslide dams. Dams are upstream $(0.7 \mathrm{~km})$ from a cluster of structures. River is flowing to the west. $C$, Three landside dams with visible pooling. Dams are upstream $(3.5 \mathrm{~km})$ from clusters of structures and a road. River is flowing to the south. $D$, Landside dam with visible pooling. The dam is upstream $(2 \mathrm{~km})$ from clusters of structures and a road. River is flowing to the west. $E$, Landslide dam; unknown if the dam is completely or partially blocking river. The dam is upstream $(1.4 \mathrm{~km})$ from densely populated areas, structures, and roads that are adjacent to and intersect the river channel farther downstream. River is flowing to the north. N, north; W, west. 


\section{Ongoing Hazards}

Hazards associated with the landslides triggered by this earthquake may pose a risk to people on the Tiburon Peninsula for several years. The following hazard assessment is based on our preliminary and rapid analysis of satellite imagery coupled with lessons learned from scientific studies of postearthquake hazards in other locations. Remotely sensed data alone cannot be used to accurately determine hazard; ideally, a remote investigation would be accompanied by field reconnaissance. This preliminary report provides information that can be used to guide future field investigations.

\section{Landslide Dams}

Thousands of landslides deposited debris in channels, some of which created landslide dams that impounded water (fig. 8). A primary concern with these landslide dams is their potential to fail catastrophically and send a flood surge downstream (Fan and others, 2019). A flood surge, which could occur without warning, could affect people living downstream and result in the loss of life and damage to homes and infrastructure. The timing of dam failure and the magnitude of a potential flood surge are controlled by several factors, such as dam size and geometry, flow rates, and dam material characteristics (Costa and Schuster, 1988), that cannot be determined from remotely sensed data alone. Debris dams are best assessed onsite, and therefore, we cannot provide detailed hazard or risk assessments herein. However, using high-resolution satellite imagery, we identified 292 landslides that could be restricting streamflow. Most were small and had already breached or been eroded by the time imagery was collected. However, we flagged 35 of these landslides as being of potential concern because of proximity to structures, relative size of the potential dam, and potential downstream effects (in other words, people and property existing less than 4-km downstream from the landslide). Of the 35 flagged dams, we identified 20 with water pooling upstream at the time the imagery was collected (imagery dates ranged from August 14, 2021, to October 10, 2021).

Most landslide dams fail within 10 days of formation, usually by overtopping (Costa and Schuster, 1988). Over time, some dams stabilize as water erodes a new path across or through the landslide deposit, in some cases forming a natural spillway over bedrock or by channel armoring (Costa and Schuster, 1988). If erosion is slow and deposits are thin, the flowing water may erode a new channel, which decreases the likelihood of a catastrophic dam failure. A concerning scenario is a large, impervious debris dam that impounds a large pool upstream and eventually catastrophically fails from overtopping, piping, or slope failure (Fan and others, 2019). We saw no large dams of urgent concern, such as those with signs of rapid downcutting or piping through a large dam impounding substantial amounts of water. However, field verification would be necessary to assess this hazard more accurately because of the limitations of satellite imagery for making such assessments. We include details of the landslide dams flagged as being of concern in table 1. Another potential long-term concern is that the imagery indicates that many channels into which numerous landslides deposited debris had no flowing water at the time the imagery was collected. This indicates possible unknown dams could start to impound water following substantial rainfall.

\section{Landslide Hazards to Roads}

Continued landslide activity adjacent to roads is likely to occur where destabilized debris or areas of cracking are present above or below the roadway. Continued landslides are likely during or after periods of rainfall or earthquake aftershocks. Numerous areas of minor rockfall along roads throughout the affected region may continue to affect roads (fig. 2). The landslide inventory probably underrepresents landslides affecting roads because steep road cuts and more subtle road damage are difficult to determine in satellite imagery. The current area of greatest concern is a mountain pass along Route Nationale 7 (RN-7), the main highway connecting Les Cayes and Jérémie, where a series of landslides blocked the road (see R1 in table 1, fig. $3 B$ ). The road has been cleared of landslide debris (as of August 22, 2021, imagery), but substantial debris remains on the slopes above the road. Destabilized material is likely to ravel onto the road; aftershocks, rainfall, excavation, and vibrations from passing traffic could accelerate the process. Subsequent larger landslides are also possible.

\section{Increased Landslide Activity}

Based on global studies of past earthquakes summarized by Fan and others (2019), an increase in landslide activity on the Tiburon Peninsula is likely for several years. The increase in expected landsliding relative to pre-earthquake activity is from, in part, the earthquake shaking that opened fractures that weakened rock and facilitated increased water infiltration. This slope damage and water infiltration destabilizes slopes and thus increases the likelihood of more landslides. Also, landslide debris deposited on steep slopes during the earthquake could be remobilized. However, the number of landslides in this postearthquake period will likely be far fewer than the number that were triggered by the earthquake.

Debris flows, not commonly triggered directly by earthquakes, are likely to pose a greater hazard in coming years, as they can mobilize the landslide debris that was deposited in channels. Debris flows are destructive flows of rock, soil, and water that can travel down steep channels for long distances at high speed and generally are triggered by intense rainfall. Debris flows can pose risks to low-lying settlements and infrastructure along channels and near rivers. After an earthquake, debris flows tend to be triggered by lower-intensity rainfall 

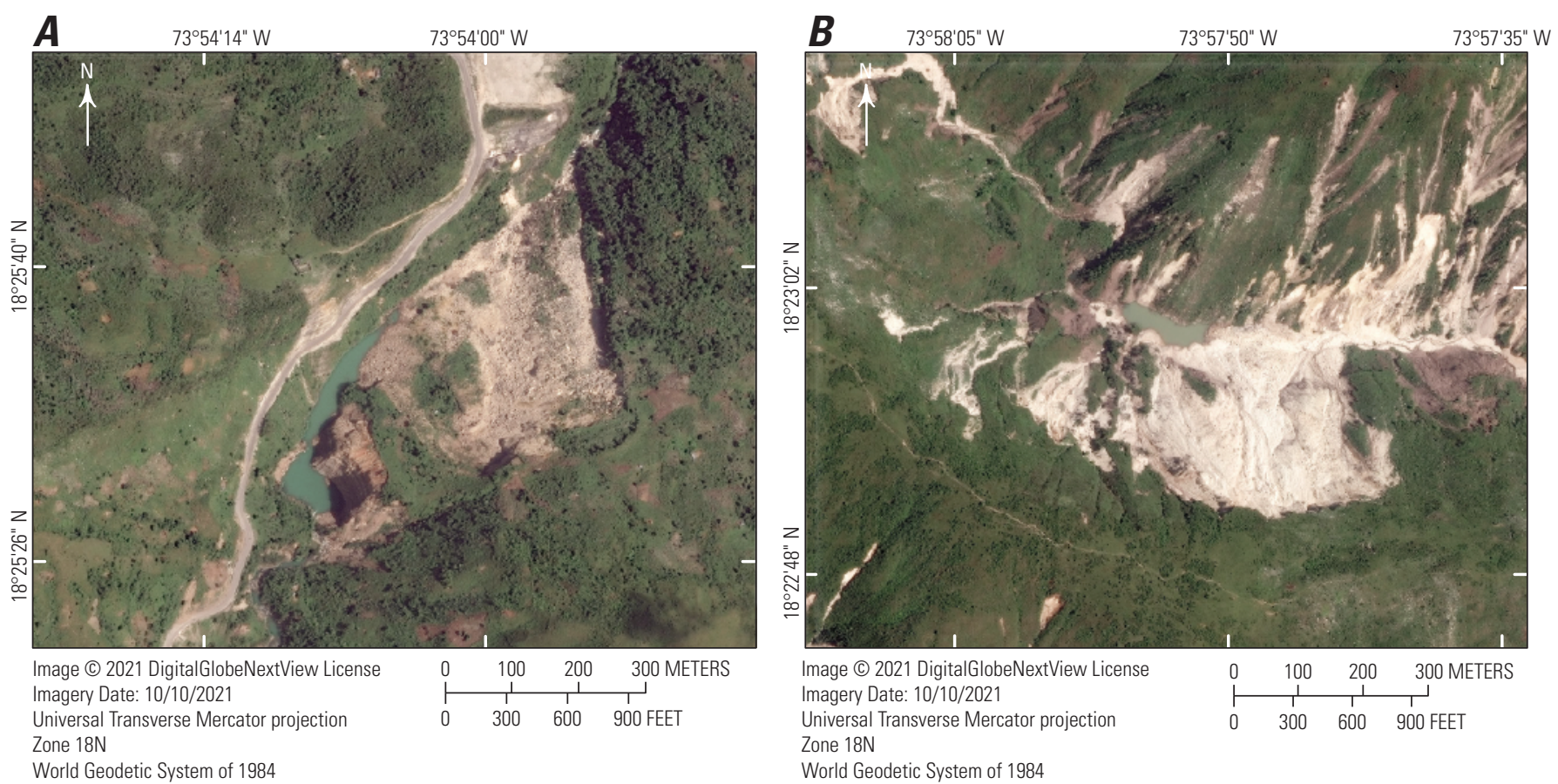

Figure 8. Satellite imagery from Haiti after the 2021 earthquake and examples of two landslide dams that were flagged as warranting continued monitoring. $A$, Landslide dam (D24 in table 1) in Pestel commune with visible pooling. It is not possible to discern from the satellite imagery if the dam is impassable. The river is flowing to the northeast. $B$, Landslide dam (D39 and D40 in table 1) in Beaumont commune with visible pooling. The river is flowing to the east. N, north; W, west.

thresholds than before the earthquake, and this increased sensitivity can last from a few years to a decade or longer (Fan and others, 2019).

Landslides can occur without a specific obvious trigger at any time but are more likely to be concentrated during periods of intense or prolonged precipitation or aftershock activity.

Debris flows also can be triggered by catastrophic landslide dam failures. The Atlantic tropical storm season (June-November), which peaks around mid-September through mid-October, is a period of significant concern for both landslide and debris flow hazards because of intense rain associated with tropical storms.

The likely footprint for increased landslide hazards is the area where earthquake-triggered landslides most occurred, as defined by (1) the USGS Ground Failure product landslide model and (2) the mapped landslide locations (fig. 1). Debris flows also can reach beyond these steeper areas, as discussed. Areas of greatest continuing hazard are upslope from or adjacent to landslides triggered by the earthquake, which can remain unstable for several years. These landslides can cause many of the same issues as those triggered during the earthquake, such as direct casualties, damage to buildings and infrastructure, landslide dams, and road obstructions.

Debris flows are most likely to occur in steep drainages where the landslides triggered during the earthquake deposited sediment in and along channels (Fan and others, 2019); these hazards could be especially high along the channels having moderate to very high landslide density (fig. 9). The relative density of landslides along 1,000-m river segments is shown in figure 9. For each segment, we counted all landslides within $500 \mathrm{~m}$ on both sides of the channel and assigned a relative landslide density for that segment. The analysis may doublecount landslide points in adjacent 1,000-m segments and does not consider the size of the landslide or whether it reached the channel. Although most debris flows stop upon reaching a larger, flatter channel, large debris flows can travel greater distances (Iverson and others, 1997). Large debris flows can form when several smaller debris flows coalesce during intense rainfall or can mobilize from large landslides that contain or incorporate sufficient water. Figure 9 does not show the hazard or risk from these large, long-traveled debris flows.

\section{Channel Sedimentation and Flooding}

The large amount of landslide debris in and above rivers and streams is a potential long-term hazard of riverbed sedimentation, aggradation, and consequent increased downstream flooding. Many landslides triggered by the earthquake deposited sediment in stream and river channels, and this debris may migrate down the river networks for several years or longer (Fan and others, 2019). Although most of the landslides are small, the combined contribution of sediment to the river can be substantial where landslides were abundant. This sediment can accumulate where the river channel is less steep, where there are natural constrictions, and (or) where streamflow is slower. For example, we mapped more than 1,000 landslides in a $15-\mathrm{km}$ 


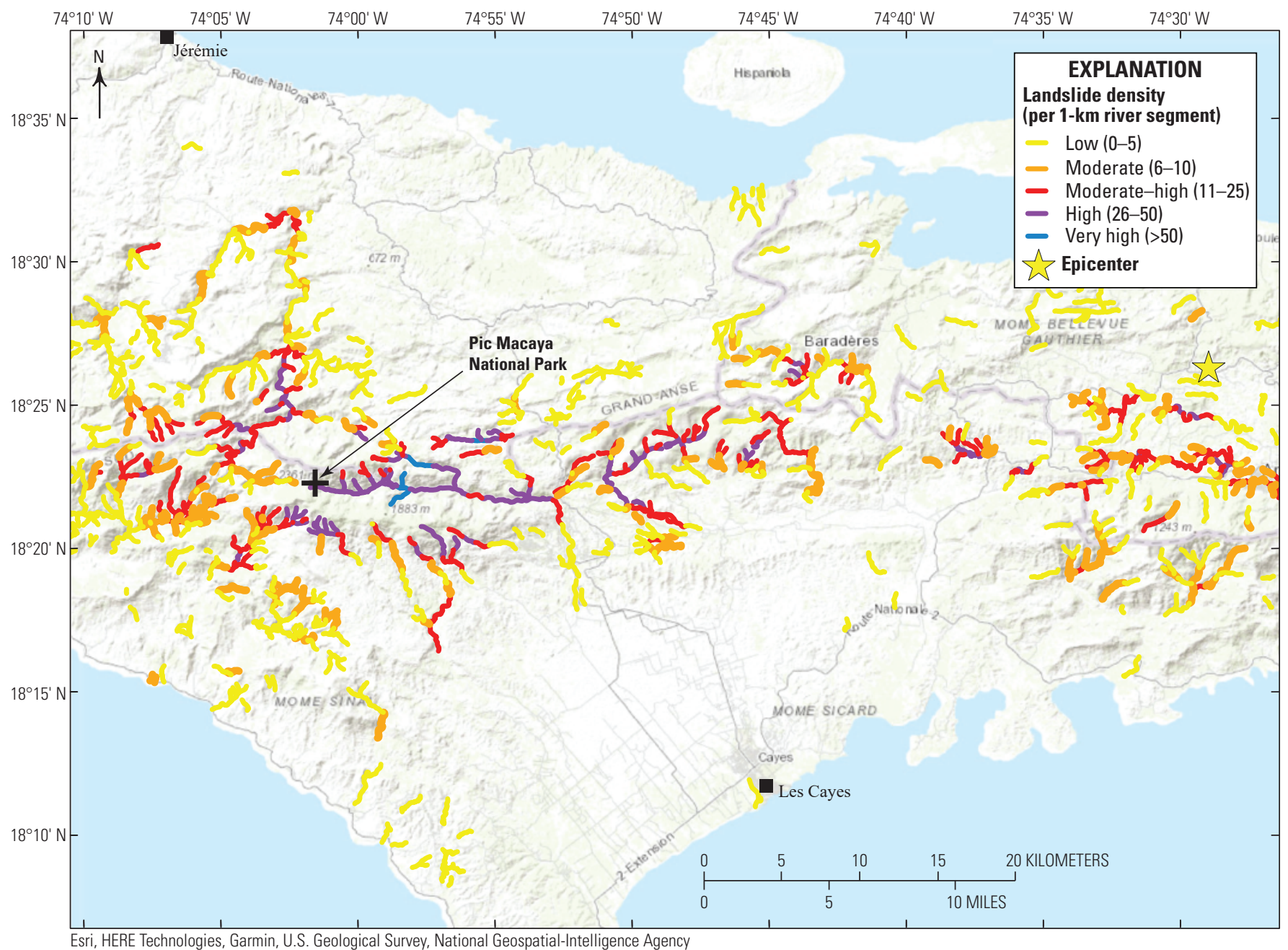

Figure 9. Map showing the relative density of landslides along 1,000-meter $(\mathrm{m})$ river segments on the Tiburon Peninsula, Haiti, after the 2021 Nippes earthquake. For each segment, we counted all landslides within $500 \mathrm{~m}$ on both sides of the channel and assigned a relative landslide density for that segment. The analysis may double-count landslide points in adjacent 1,000-m segments and does not take into consideration the size of the landslide or whether it reached the channel. Low density is defined as $0-5$ landslides per segment, moderate is $6-10$, moderate-high is $11-25$, high is $26-50$, and very high is greater than 50 . This map does not show the hazard or risk associated with large, long-traveled debris flows. The relative density of landslides that may have directly contributed sediment to channels illustrates the drainages most likely to experience changes to flooding behavior. This map does not depict potential hazards to downstream segments. $\mathrm{N}$, north; W, west; km, kilometer; >, greater than.

segment of the Ravine du Sud River in the Pic Macaya National Park. These landslides created a potential hazard on the Ravine du Sud River between Camp-Perrin and Les Cayes, where the river gradient is low, and people live near the river. As the sediment is deposited in channels, it can reduce the capacity of the channels for carrying water and thus make flooding more likely. In this situation, water levels generally will be higher for the same discharge, and overland inundation will be more frequent and deeper. This hazard will persist until the recently deposited sediment is flushed out of the river system. The relative density of landslides that may have directly contributed sediment to channels is shown in figure 9 and illustrates the drainages most likely to experience changes to flooding behavior but does not depict potential hazards to downstream segments.

\section{Summary}

Satellite imagery was used to map landslides associated with the 2021 magnitude 7.2 Nippes, Haiti, earthquake. We performed a preliminary hazard analysis by identifying landslides that may pose a threat to people and property. There are limitations to performing a hazard analysis remotely, and thus, further investigation and monitoring would be beneficial to accurately determine the threats posed by these hazards. Our findings are summarized as follows:

- The Tiburon Peninsula will continue to experience ongoing hazards related to the landslides triggered by the earthquake. 
- A minimum of 4,893 landslides were triggered by the earthquake and possibly Tropical Cyclone Grace.

- We observed 292 landslide dams, 35 of which may warrant additional investigation and continued monitoring (see table 1).

- We identified 116 landslides, 4 of particular concern, that likely affected roads by rendering them impassable or susceptible to subsequent damage from existing landslides (see table 1).

- There will be an increased likelihood of flooding, including water and debris surges, in watersheds that experienced numerous landslides.

- There will be an increased likelihood of landslides triggered by rainfall and aftershocks for several years.

- There will be an increased likelihood of flood surges from landslide dam failures, some of which may not have been identified in this iteration of mapping.

\section{References Cited}

Allstadt, K.E., Thompson, E.M., Jibson, R.W., Wald, D.J., Hearne, M., Hunter, E.J., Fee, J., Schovanec, H., Slosky, D., and Haynie, K.L., 2021, The U.S. Geological Survey ground failure product-Near-real-time estimates of earthquake-triggered landslides and liquefaction: Earthquake Spectra, accessed November 18, 2021, at https://doi.org/10.1177/87552930211032685.

Bureau des Mines et de l'Énergie, 2005, Carte Géologique de la République d'Haiti [Geological map of the Republic of Haiti]: République d'Haït, Bureau des Mines et de l’Énergie, scale 1:250,000, accessed November 18, 2021, at https://haitidata.org/layers/geonode_data:geonode:hti_ geology_geology_polygon_082005. [In French.]

Costa, J.E., and Schuster, R.L., 1988, The formation and failure of natural dams: Geological Society of America Bulletin, v. 100, no. 7, p. 1054-1068, accessed November 19, 2021, at https://doi.org/10.1130/00167606(1988) $100<1054$ :TFAFON $>2.3 . C O ; 2$.

Facebook Connectivity Lab and Center for International Earth Science Information Network, 2016, High resolution settlement layer (HRSL): Columbia University, accessed August 19, 2021, at https://www.ciesin.columbia.edu/ data/hrsl/.
Fan Xuanmei, Scaringi, G., Korup, O., West, A.J., van Westen, C.J., Tanyas, H., Hovius, N., Hales, T.C., Jibson, R.W., Allstadt, K.E., Zhang Limin, Evans, S.G., Xu Chong, Li Gen, Pei Xiangjun, Xu Qiang, and Huang Runqui, 2019, Earthquake-induced chains of geologic hazards-Patterns, mechanisms, and impacts: Reviews of Geophysics, v. 57, no. 2, p. 421-503, accessed November 18, 2021, at https://doi.org/10.1029/2018RG000626.

Fox, B., 2021, U.S. airlifts aid to Haiti to reach areas hardest hit by quake: The Associated Press, accessed November 18, 2021, at https://apnews.com/article/caribbean-haiti-3e 076b660e9afe03a93bdd4f72288a9e.

HaitiData and The World Bank, 2021, Haiti digital terrain model 2014-2016: Distributed by OpenTopography, accessed October 1, 2021, at https://doi.org/10.5069/ G9GX48R8.

Harp, E.L., Jibson, R.W., and Schmitt, R.G., 2016, Map of landslides triggered by the January 12, 2010, Haiti earthquake: U.S. Geological Survey Scientific Investigations Map 3353, 15 p., 1 sheet, scale 1:150,000, accessed November 18, 2021, at https://doi.org/10.3133/sim3353.

Iverson, R.M., Reid, M.E., and LaHusen, R.G., 1997, Debrisflow mobilization from landslides: Annual Review of Earth and Planetary Sciences, v. 25, no. 1, p. 85-138, accessed November 18, 2021, at https://doi.org/10.1146/annurev.ear th.25.1.85.

Jibson, R.W., and Harp, E.L., 2011, Field reconnaissance report of landslides triggered by the January 12, 2010, Haiti earthquake: U.S. Geological Survey Open-File Report 2011-1023, 19 p., accessed November 18, 2021, at https://doi.org/10.3133/ofr20111023.

Keefer, D.K., 2002, Investigating landslides caused by earthquakes-A historical review: Surveys in Geophysics, v. 23 , no. 6 , p. $473-510$, accessed November 18, 2021, at https://doi.org/10.1023/A:1021274710840.

Malamud, B.D., Turcotte, D.L., Guzzetti, F., and Reichenbach, P., 2004, Landslide inventories and their statistical properties: Earth Surface Processes and Landforms, v. 29, no. 6, p. 687-711, accessed November 19, 2021, at https://doi.org/ 10.1002/esp.1064.

Martinez, S.N., Allstadt, K.E., Slaughter, S., Schmitt, R., Collins, E., Schaefer, L.N., and Ellison, S., 2021, Rapid response landslide inventory for the 14 August 2021 M 7.2 Nippes, Haiti Earthquake: U.S. Geological Survey data release, accessed December 7, 2021, at https://doi.org/10.5066/P99MYPXK. 
National Oceanic and Atmospheric Administration, 2021, Tropical Depression Grace: National Hurricane Center and Central Pacific Hurricane Center Bulletin, accessed November 12, 2021, at https:/www.nhc.noaa.gov/archive/ 2021/a107/al072021.public.010.shtml.

OpenStreetMap, 2021, Map data OpenStreetMap contributors: OpenStreetMap website, accessed November 19, 2021, at https://www.openstreetmap.org/.

Saint Fleur, N., Klinger, Y., and Feuillet, N., 2020, Detailed map, displacement, paleoseismology, and segmentation of the Enriquillo-Plantain Garden Fault in Haiti: Tectonophysics, v. 778, p. 228368, accessed November 18, 2021, at https://doi.org/10.1016/j.tecto.2020.228368.
Somerville, P.G., Smith, N.F., Graves, R.W., and Abrahamson, N.A., 1997, Modification of empirical strong ground motion attenuation relations to include the amplitude and duration effects of rupture directivity: Seismological Research Letters, v. 68, no. 1, p. 199-222, accessed November 18, 2021, at https://doi.org/10.1785/gssrl.68.1.199.

United Nations Children's Fund, 2010, UNICEF Haiti emergency response update, March 1, 2010: UNICEF Situation Report, accessed November 18, 2021, at https://reli efweb.int/report/haiti/unicef-haiti-emergency-responseupdate-1-march-2010.

Washington Post, 2021, Photos - The scene in Haiti in the aftermath of a major earthquake: Washington Post, accessed November 18, 2021, at https://www.washingtonpost.com/ photography/interactive/2021/deadly-earthquakestrikes-haiti/. 


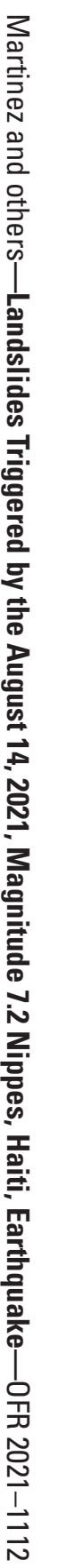

